\section{International Journal of

DOI: 10.31695/IJASRE.2019.33461
E-ISSN : 2454-8006

Volume 5, Issue 8

August - 2019

\title{
Solar Water Heating Systems Potential in Nigeria- A Review
}

\author{
Sirajo Alhassan ${ }^{1}$, Badamasi Haruna ${ }^{1}$, Dauda Garba ${ }^{1}$, Mustapha Usman ${ }^{1}$, Adamu Baba Wada ${ }^{2}$ and \\ Sagir Lawan Waziri ${ }^{3}$ \\ ${ }^{1}$ Department of Mechanical Engineering, Bayero University, Kano, Nigeria \\ ${ }^{2}$ Department of Welding and Fabrication Technology, Jigawa State Polytechnic Dutse \\ ${ }^{3}$ Department of Mechanical Engineering, School of Technology, Kano State Polytechnic
}

Nigeria

\begin{abstract}
A review of solar water heating systems potential in Nigeria with their applications is presented. Thus, the paper presents an extensive study of the research carried out on the solar water heating system. In the present study, both experimental and theoretical developments in the field of solar water heater have been reviewed thoroughly. Extensive study has been conducted to further optimize the thermal efficiency of solar water heating. The paper provides a consolidated summary of the various types and components of solar water heating system that includes collector, storage tank and heat transfer fluid. Review of related past works done is included in this paper that shows different approaches from different researchers in order to improve the system efficiency. In addition to this, detailed findings and discussion on the limitations of existing research, research gap and recommended possible modifications is made.
\end{abstract}

Key Words: Solar water heater, Nigeria, Collector, Storage tank, solar energy, Heat exchangers.

\section{INTRODUCTION}

Solar water heating is an acknowledged innovation and is progressively being utilized as one of the cost-effective methods for heating water in private and open structures, for example, lodgings, laundries, eateries, clinics and health centers [1]. Hot water is fundamental both in industries and homes. It is required for cleaning up, washing garments and utensils, and other residential purposes in both the urban and rural areas. Hot water is likewise required in extensive amounts in hotels, hospitals, and industries, for example, material, paper, and nourishment preparing of dairy and palatable oil. Solar water heating systems can heat water from ambient to temperatures more than $90^{\circ} \mathrm{C}$ depending upon the collector type utilized and climate conditions in a targeted location. Utilizing solar collector to heat water can without much of a stretch achieve required temperatures. The energy saved from using a solar water heating system assist to reduce energy request from power utilities. A solar water heater is a long term investment that will save fund spent on water heating after the system has paid for itself.

Currently, most of the commercial and industrial hot water demands in Nigeria are met mainly by the use of electric heaters. Regrettably, electric heaters became less attractive due to depleting nature of conventional energy sources being use, environmental concerns and the energy cost rise.

This is because the primary energy sources of electric energy utilized are mainly the fossil fuels [2]. In addition, the demand for electricity is growing rapidly; thus within cold weather periods normally mornings and evenings when hot water demand is highest, the electrical energy facilities are often overstretched, resulting in some cases to power shedding. These issues can be dealt with by removing part of the energy demand for hot water purposes from electricity by utilizing solar water heater.

For many years, solar domestic hot water systems have gained great attention due to their considerable energy conservation, environmental protection and relatively good economy. The study provides a critical review on solar water heating systems potentials in Nigeria based on available published papers. The demand for energy is consistently increasing as a result of the energy crises of 1970s, population increase, and modernization [3]. Therefore, the need to embrace a cost-effective and sustainable alternative to our depleting conventional energy sources has become important. Also, the usage of solar water heating systems in the Nigeria is relatively low despite the fact that the region being well endowed with solar energy resource especially northern region of the country. 
A solar water heating system is the device that uses solar energy for hot water production. Solar water heating system is renewable energy technology and has been used in many countries of the world. This natural energy is absolutely free and the supply is unlimited in the day whenever there is sunlight. The usage of this energy does not produce any pollutant and therefore is most Environment Friendly. In private nations, energy utilization in the structure needs of a high energy budget. Most energy is needed for production of hot water and space heating. Hot water is important for bathing and for washing, utensils and other domestic purpose in urban as well as in country areas. Heating water is usually by burning fuel wood in the country areas and by fossil fuel energy such as kerosene oil, petroleum gas (LPG), coal and electricity in metropolitan areas.

Solar water heating systems are available in different forms and can be used in different application. Domestic hot water usually uses small system applications while larger systems are used in industrial applications [4].

Suitable design of solar water heating system will give maximum benefit to the user, mainly for a large system. Designing solar water heating system needs suitable sizing of different components, solar resources and hot water demand. In this review, the effect of sizing of part on the system is studied and a novel strategy for the system part is proposed to improve the design and performance of solar water heating systems.

\subsection{Types of solar water heating system}

Solar water heaters come in various setups in the design, cost, performance, and size of system. Most systems have a backup to complement when there is no sunshine, for example, electricity or gas. A solar water heating system comprises a solar collector, storage tank, a back-up energy source, a pump and controls. [5].

As per [6], these systems can be grouped into three primary classifications:

\subsubsection{Active Systems}

Active systems utilize electric pumps, valves, and controllers to facilitate flow of water or other heat transfer fluids through the collectors. Along these lines, the active systems are additionally called forced circulation systems and can be direct or indirect. The active system is additionally classified into two categories:

- Open-loop (Direct) Active System

- Closed-loop (Indirect) Active System

(1) Open-Loop Active Systems: Open-loop active systems utilize pumps to flow water through the collectors. This design is effective and reduces the operating cost of the system however is not suitable if the water is hard or acidic in light of the fact that scale and corrosion rapidly incapacitate the system. These systems are prevalent in non-freezing climate.

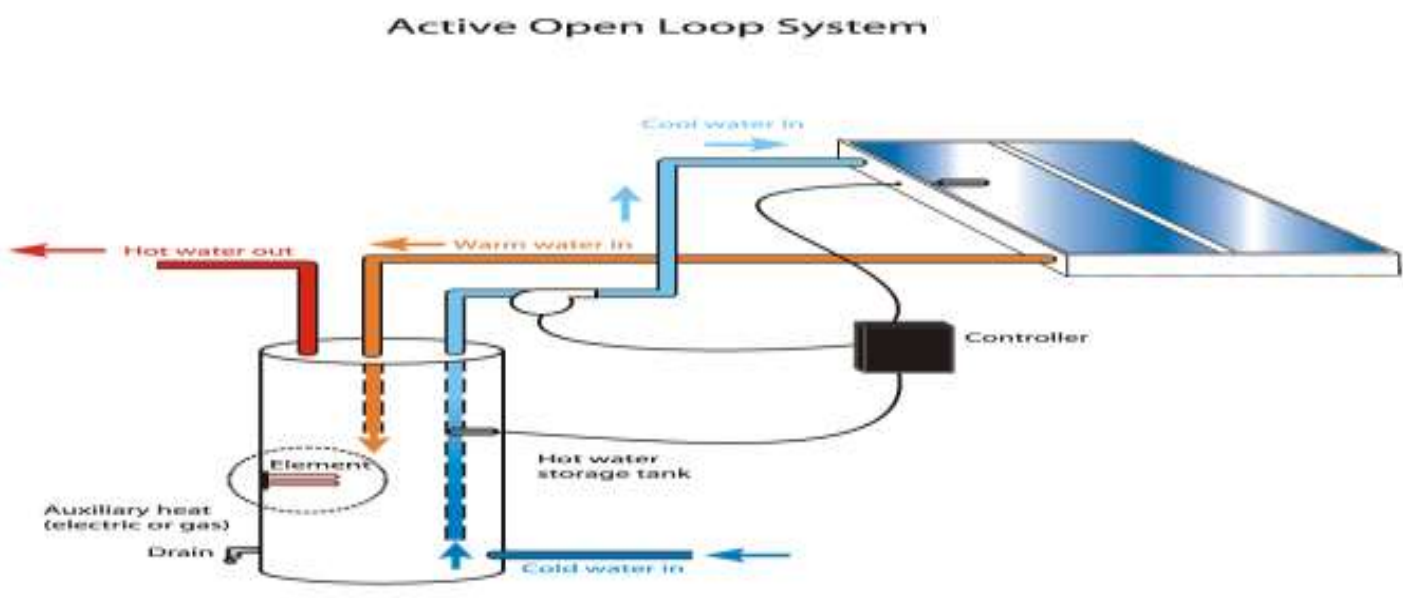

Figure no. 1.Active Open Loop Solar Water Heating System

(2) Closed-Loop Active Systems: These systems circulate heat transfer fluids using a pump (frequently a glycol-water antifreeze mixture) through collectors. Heat exchangers transfer the heat from the liquid to the household water stored in the tanks. Closed-loop glycol systems are prominent in zones subject to extended freezing temperatures since they offer great freeze protection. 


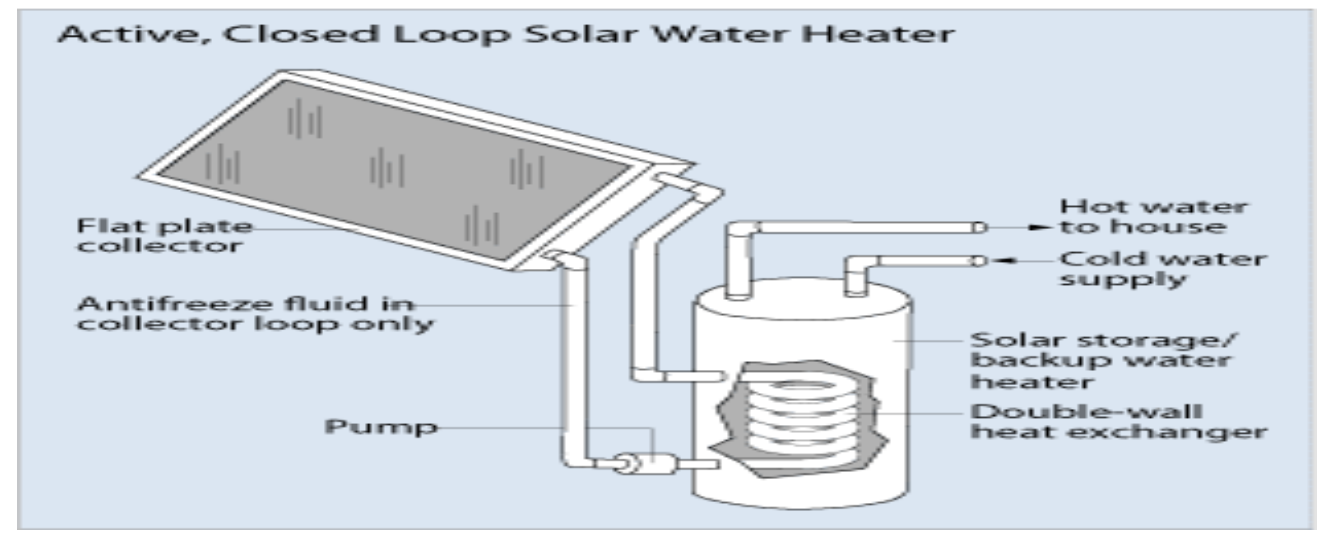

Figure no. 2.Active Closed Loop Solar Water Heating System

\subsubsection{Passive Systems}

Passive systems basically circulate water or a heat transfer liquid by natural convection between a collector and a raised storage tank (over the collector). The principle is straightforward, as the liquid heats up its density reduces. The liquid ends up noticeably lighter and ascends to the highest point of the collector where it is drawn to the storage tank. The liquid which has chilled off at the foot of the storage tank at that point streams back to the collector. Passive systems can be more affordable than active systems; however they can likewise be less effective. Thermosiphon system is the best example of passive systems.

Thermosiphon Systems: In the thermosyphon system, water streams from the overhead tank to the base of the collector by natural circulation and water flows from the collector to storage tank as long as the absorber continues absorbing heat from the sun and water gets heated in the collector. The cold water at the base of storage tank keeps running into the collector and replaces the hot water, which is then forced inside the insulated high temp water storage tank. The process of the circulation stops when, there is no solar radiation on the collector. Thermosiphon system is straightforward and requires less maintenance due to the no presence of instrumentation and controls. Performance of a collector relies upon the difference between collector temperature and ambient temperature and inversely proportional to the intensity of solar radiation.

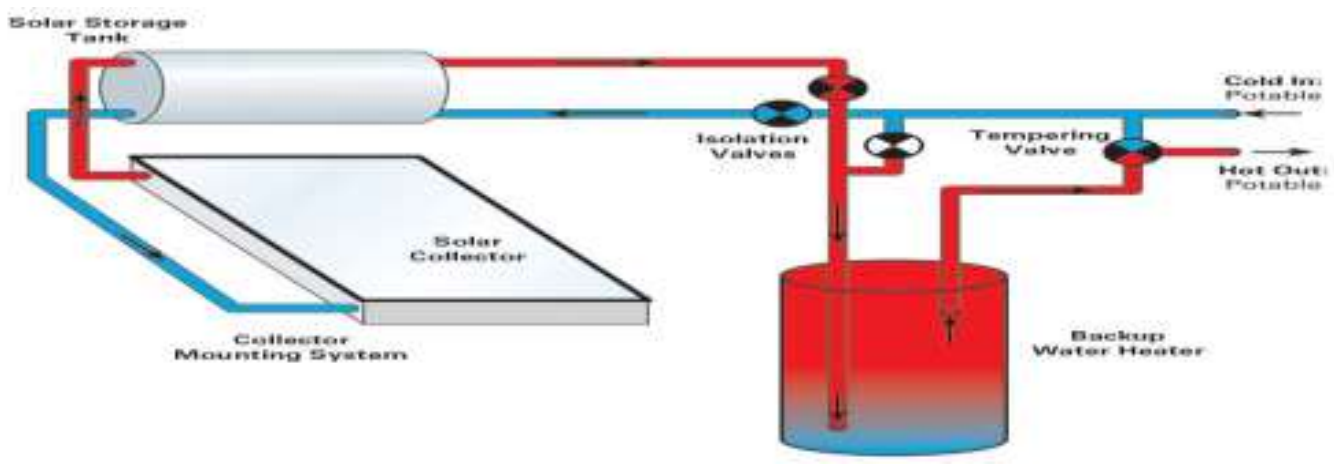

Figure no. 3. Thermosyphon Solar Water Heating System

\subsubsection{Batch Systems}

Batch System (otherwise called integral collector storage system) are simple passive system comprising of at least one storage tanks set in an insulated box that has a coated side facing the sun. Batch systems have joined collection and storage functions. Depending upon the system, there is no prerequisite for pumps or moving parts, so they are not expensive and have few parts to operate. 


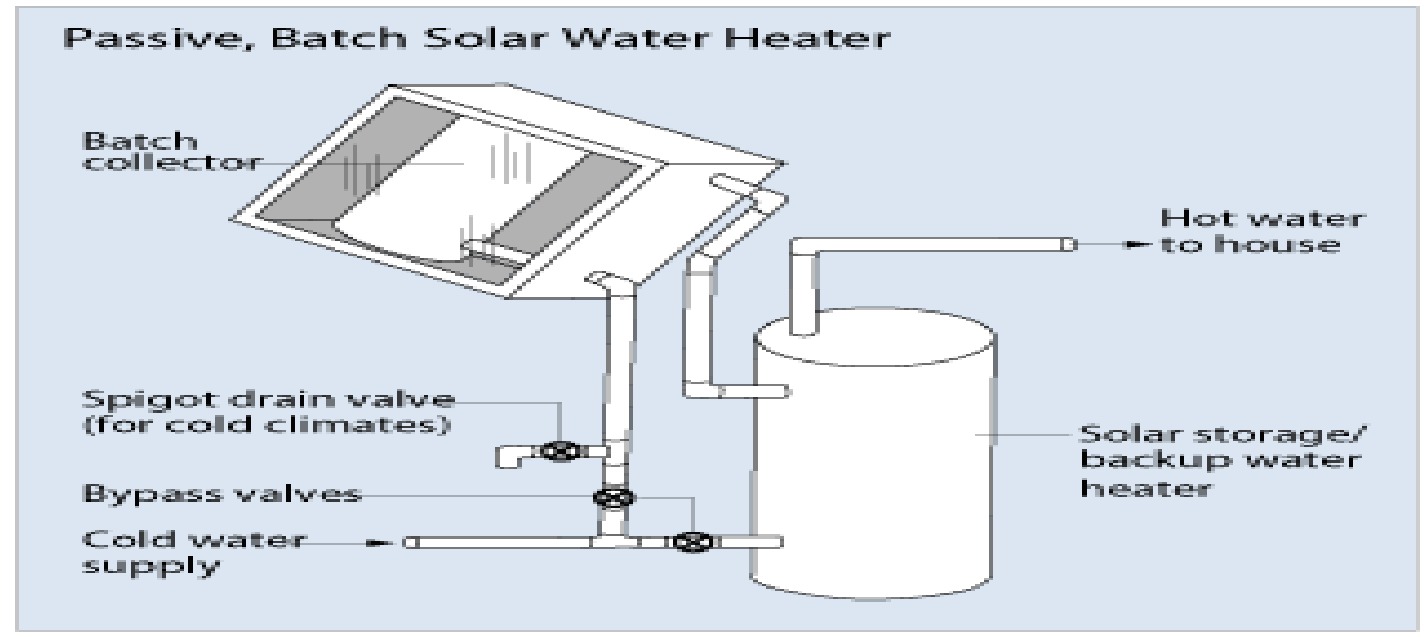

Figure no. 4. Passive, Batch Solar Water Heating System

\section{COMPONENTS OF SOLAR WATER HEATING SYSTEM}

Solar water heating system for the most part comprises of a solar radiation collector panel, a storage tank, a pump, a heat exchanger, connecting pipes, and auxiliary heating unit. Some of important parts are discussed beneath.

\subsection{Solar Collectors}

The selection of collector is associated by the heating demand and the environmental conditions in which it is used. There are principally three types of solar collectors namely flat plate solar collector, evacuated tube solar collector, concentrated solar collector.

\section{(1) Flat Plate Collectors}

Flat plate collectors are utilized broadly for local water heating applications. It is straightforward in design and has no moving parts it requires little maintenance. It is an insulated, weatherproofed box containing a dark absorber plate under at least one transparent covers. They collect both direct and diffuse radiation.

\section{(2) Evacuated-Tube Collectors}

Evacuated tube collectors are the most common solar thermal technology in China and in the World. They make use of a glass tube to surround the absorber with high vacuum and effectively resist atmospheric pressure. The vacuum that surrounds the absorber greatly reduces convection and conduction heat loss, therefore achieving greater energy conversion efficiency. The absorber can be either metallic as in the case of flat plate collectors or being a second concentric glass tube ("Sydney Tube"). Heat transfer fluid can flow in and out each tube or being in contact with a heat pipe reaching inside the tube. For the latter, heat pipes transfer heat to the fluid in a heat exchanger called a "manifold" placed transverse in respect to the tubes. The manifold is wrapped in insulation (glass wool) and covered by a protective metal or plastic case also used for fixing to supports.

\section{(3) Concentrating Collectors}

Concentrating collectors utilize reflected surfaces to focus the sun's energy on an absorber called a receiver. Heat transfer fluid flows through the receiver and absorbs heat. These collectors achieve considerably higher temperatures than flat plate collectors and evacuated tube collectors, yet they can do so in as much as direct sunlight is available.

\subsubsection{Storage Tank}

Most financially available solar water heaters require an all-around insulated storage tank. Storage tank is made of high pressure opposed stainless steel secured with the insulated fiber and aluminum foil. Some solar water heaters utilize pumps to circulate hot water from storage tanks through collectors and uncovered piping.

\subsubsection{Heat Transfer Fluid}

A heat transfer fluid is utilized to receive the heat from collector and transfer to the storage tank either directly or with the assistance of heat exchanger. Keeping in mind the end goal to have a productive SHW setup, the fluid ought to have high specific heat capacity, high thermal conductivity, low viscosity, and low thermal expansion coefficient, anti-corrosive property or more all minimal effort. Among the basic heat transfer liquids, for example, water, glycol, silicon oils and hydrocarbon oils, the water ends up being the best among the liquids. Water is the least expensive, most promptly available and thermally efficient liquid yet does freeze and can cause corrosion. 


\subsubsection{Heat Exchanger}

In an indirect type of solar water heating system, a heat exchanger is used to transfer solar heat absorbed from the working fluid to the storage tank. The heat exchangers are mostly produced from conductive materials for example aluminum, stainless steel, cast iron, copper, steel, and bronze. To guarantee good thermal conductivity and resistance to corrosion, copper is generally employed in solar water heating system. Numerous arrangements of heat exchangers have been designed for indirect water heating storage and the most normal arrangements are: the immersed coil-in-tank, the shell-and-tube, and the mantle heat exchanger [7]. A few designs of heat exchangers have been proposed to enhance the general performance of the SWH system [8].

\section{REVIEW OF PAST WORKS ON SOLAR WATER HEATING SYSTEM IN NIGERIA}

Many research projects comprising design, modeling, simulation, and testing of solar water heaters have been conducted within the nation [9]. A lot of samples of these systems have been built and optimized and are ready to be in the market. Some systems have been installed in houses and hospital buildings in the nation.

Research led before in the field of solar water heating system in Nigeria by [10] in which they explored the techniques for optimizing the performance of flat plate collectors by making the collection to track the sun. Full tracking and semi tracking techniques were explored for five Northern area including Kaduna, Kano, Zaria, Jos and Sokoto, their outcome demonstrated higher energy gains by flat plate collectors could be accomplished by working them in various sun tracking modes.

[11], at the Sokoto Energy Research Center (SERC, UDU) designed, construct and tested four solar water heating systems which were set up in a thermosyphonic arrangement. The absorbers of the collectors were made as: flat plate dark painted aluminum sheet, flat plate dark separated galvanized mild steel sheets, quasi flat plate zinc covered mild galvanized aluminum sheet and quasi flat plate zinc covered mild galvanized sheet. The performance evaluation of these collectors indicated that, the dark painted flat plate galvanized sheet gave the highest water outlet temperature while dark painted aluminum flat plate produced the highest efficiency values.

[12] designed, constructed and tested a solar water heating system for Bayero University, Kano, New campus clinic, the system was made to operate on thermosypon principle. The system was tested with an average solar radiation of $650 \mathrm{~W} / \mathrm{m}^{2}$. Two flat plate collectors was used $1 \mathrm{~m}^{2}$ each with single glazing, the surface of the collectors was darkened with black paint of absorptivity 0.95 and emissivity of 0.09 to improve its absorption capacity. Readings were taken for a period of three months in April, May and June with minimum ambient temperature of $32^{\circ} \mathrm{C}$. Maximum hot water temperature inside the tank and the collector outlet temperature were found to be $69.5^{\circ} \mathrm{C}$ and $80.5^{\circ} \mathrm{C}$ respectively. The highest maximum daily collector efficiency was found to be $48.67 \%$. A temperature of $56^{\circ} \mathrm{C}$ was also recorded by 07:00hours in the morning. The outcome of the experiment established the fact that the system could satisfy the hot/warm water demand of the clinic.

[13] Studied the effect of absorber orientation on the performance of flat plate solar collectors, the collectors corrugated and plain types of different absorber configuration was developed and tested under variable conditions. Based on corrugated collector performance data, a temperature of $73^{\circ} \mathrm{C}$ was realized for 50 liters of heated water. While the flat plate plain absorber attained a maximum of $68^{\circ} \mathrm{C}$. They also found that the collector plate temperature was $118^{\circ} \mathrm{C}$ from the corrugated absorber and $101^{\circ} \mathrm{C}$ for the plain flat plate collector absorber.

[14] Study the effect of tube spacing as a design factor in the performance of a natural circulation solar water heater using Zinc, Copper and Galvanized steel absorber plate. They investigated the collector performance in terms of collector fin efficiency to obtain both theoretical and computer aided simulation based on Hottel Wheller model of the system. The result indicated that the tube spacing varies inversely with both collector efficiency and fin efficiency for the absorber plate. Copper shows the best performance.

[15] Designed, developed and tested solar water heater in Akure, Nigeria. He utilizes a flat plate collector secured with twofold coating at $20^{\circ}$ angle of tilt to the horizontal surface. The surface of the collector was darkened to enhance its absorption capacity. Readings were taking for six days with an ambient temperature of $36^{\circ} \mathrm{C}$; a maximum water temperature of $73^{\circ} \mathrm{C}$ was recorded during the examination. Hourly collector's efficiency increased until $2.00 \mathrm{pm}$ when steep increase was gotten with a highest efficiency of $92 \%$ at $4.00 \mathrm{pm}$. The result of the study established the fact that solar water heating is achievable in south western Nigeria and obviously in most part of Nigeria, northern Nigeria specifically where insolation is significantly higher.

[16] Analyzed the thermal efficiency of passive solar water heaters for application in agro industries using flat plate solar collector made up absorber plate and transparent sheet of glass, water storage tank and stand. The absorber plate was made up mild steel; 
they used copper tube to form the loop on the mild steel absorber. They experimentally tested the system under the day time load conditions at Nsukka, Nigeria over the ambient temperature range of $21^{\circ} \mathrm{C}$ to $31^{\circ} \mathrm{C}$ and a daily global irradiation range of 8.3 to $17 \mathrm{MJ}$. They obtained a peak temperature rise of the heated water of $83^{\circ} \mathrm{C}$ while the daily average useful efficiency was $42 \%$. They concluded that such a system can operate successfully for agro industries and home applications in the country.

[17] developed a solar water heater using thermosyphon principles with the following components; cold water tank, hot water storage tank, solar collector and circulation system. The tanks were made with 16 gauge of galvanized steel. The hot water storage was insulted with $50 \mathrm{~mm}$ thickness of fiber glass. The collector has surface area of $1.6 \mathrm{~m}^{2}$ mounted on frames tilted to an angle of $7^{0} \mathrm{~N}$. Circulation pipes were lagged with tyro foam and synthetic leather. Performance test showed that the heater recorded a maximum temperature of $72^{\circ} \mathrm{C}$ at an average heat gain of $24 \mathrm{MW}$ per hour.

[18] Presented the result of the performance assessment of a thermosyphon solar water heater designed and constructed at the National Center for Energy Research and Development, University of Nigeria, Nsukka. Both numerical and experimental techniques were utilized as a part of investigation for the ideal performance of the system. The outcomes shows that on a clear day, a thermosyphon solar water heater of collector area $3.4 \mathrm{~m}^{2}$ and 150 liters storage capacity performing at a collector efficiency of $60 \%$ can produce hot water of up to $80^{\circ} \mathrm{C}$ temperature for the residential services of an average sized family at Nsukka.

In an investigation of solar water heating systems for residential and industrial applications conducted by [19], water heating systems were categorized into two general classifications (active and passive), each of them working in either direct or indirect mode. They revealed their exhibitions, uses and applications, and elements considered for their choice. The active systems for the most part have higher efficiencies, their values being 35\%-80\% higher than those of the passive systems. They are more complicated and costly. Appropriately, they are most suited for industrial applications where the load request is very high or in applications where the collector and water storage tank require not be near each other or for the applications in which the load requires more than one solar collector.

A solar water heating system for local use has been designed and developed utilizing locally available materials by [20]. Solar energy is absorbed by a flat-plate collector comprising of a thin absorber plate, attached with underneath of fluid conveying tubes, and positioned in an insulated casing with a glass cover having a cold and a hot water tank incorporated in the system. The radiation absorbed by the absorber plate can't escape through the glass, hence increasing its temperature. The water gets heated and streams into a storage tank through thermosyphon setup. Most extreme fluid output temperature, the collector temperature, and insolation of $55^{\circ} \mathrm{C}, 51^{\circ} \mathrm{C}$, and $1,480 \mathrm{~W} / \mathrm{m}^{2}$, separately, were acquired on a sunny day. This solar water heating system finds useful application and acts as a renewable energy resource in regions where there is abundant and consistent sunlight as reported by the authors.

[21] Designed, simulated, constructed and tested a thermosyphon solar water heater. The system was designed to supply a daily hot water capacity of $0.1 \mathrm{~m}^{3}$ at a minimum temperature of $70^{\circ} \mathrm{C}$ for domestic use. The design approach was in three parts; firstly, since solar radiation and weather data which are driving function for solar systems design vary randomly with time, the monthly average daily solar radiation and weather data obtained from the typical meteorological year (TMY) solar data of Zaria were used to determine the design month as the month (August) with the least monthly average daily solar energy ratio.. The results of this research led to the conclusion that a thermosyphon solar system with collector area of $2.24 \mathrm{~m}^{2}$ operated under the weather condition of Zaria, would be capable of supplying a daily domestic water of $0.1 \mathrm{~m}^{3}$ at temperature ranging from $59^{\circ} \mathrm{C}$ for the worst month (August) to $81^{\circ} \mathrm{C}$ for the best month (April). The computed Nash-Sutcliffe Coefficient of Efficiency (NSE) values of 0.663, 0.956 and 0.885 and the low RMSE values of $8.09^{\circ} \mathrm{C}, 3.65^{\circ} \mathrm{C}$ and $5.31^{\circ} \mathrm{C}$ between the modeled tank inlet temperature and the observed tank inlet temperature for the three days tests conducted indicated that the model formulated using TRNSYS software was valid and closely agreed, capable of predicting the performance of the system with a $66.3 \%, 95.6 \%$ and $88.5 \%$ degree of accuracy for the 3 days that the experiments were conducted respectively.

[22] designed, construct and tested a compact solar water heater for domestic and small scale industrial applications; it is a modification of the convectional flat plate collector for the solar water heater with use of plane reflectors to increase the energy input and improving the thermal efficiency.

A solar water heater was designed, simulated, fabricated and tested by [23]. The design, simulation, fabrication and performance tests of a thermosyphon solar water heater were carried out successfully for a block in Postgraduate hostel of Ahmadu Bello University Zaria. The fabrication was carried out using locally available materials. The solar water heater has the ability to heat 200 liters of water from a temperature of $25^{\circ} \mathrm{C}$ to a temperature of $50^{\circ} \mathrm{C}$. The design was purposely for students to use the water for bathing in order to totally discourage the use of electric heating devices in the hostel which on several occasions has been the reason of fire outbreaks in the hostel. The system factors such as costs and sizing were taken into consideration which assisted in the choice of materials and the design. The average solar radiation data was obtained from typical meteorological year (TMY) of 
Zaria which was used to determine the month with the least solar radiation. From the analysis of the typical meteorological year (TMY) data of Zaria the month of August has the least energy ratio which point it out as the month with the least solar radiation and it was used as the design month. The optimization of the system components was also carried out using MATLAB to determine the optimum system size. After the fabrication of the system the performance was evaluated by comparing the simulation results obtained from the model (solar data processor, Type 109 of TRNSYS) and the results obtained from the experiment using Microsoft Excel and standard deviation, Nash-Sutcliff coefficient statistical tools were used to validate the predictive power of the model. From the result obtained from the research it can be concluded that the thermosyphon solar water heater of collector area of $2.6 \mathrm{~m}^{2}$ has the ability to heat 200 liters of water to a temperature of $50^{0} \mathrm{C}$ in the month that has the least solar radiation in Ahmadu Bello University Samaru, Zaria. The statistical tools used for the validation of the simulation model confirm that the model is valid and can be used in the estimation of the actual characteristics of a real system. The relative error is very minimal for all the measured parameters and Nash-Sutcliff coefficient shows that the degree of fitting is very high which shows that the simulation model has high accuracy, also the standard deviation shows that the deviation of the experimental parameters from the simulated is very low and therefore it is negligible. The results show little deviation of predicted values from actual values with a good level of fit, thereby validating the model used for simulating the solar water heating system.

A Solar water heating system was designed, developed, and installed at the primary health center Danjawa village in Wamakko Local Government in Sokoto State Nigeria latitude $13^{\circ}$ by [24]. Two flat plate collectors of $1 \mathrm{~m}^{2}$ each were developed utilizing local materials available, the collectors were secured with a single coating of transparent glass. The outside of the collectors was painted with dark dull paint of emissivity of 0.95 to improve its absorption capacity of the absorber. A daily global solar radiation incident on horizontal surface of about $750 \mathrm{~W} / \mathrm{m}^{2}$ was assumed in the month of December was embraced for the design of 250 -liter capacity hot water storage tank with an extra 500 liters capacity cold water storage tank. The collectors were arranged in series and assume to work on similar efficiency. The two collectors were relied upon to heat water from a temperature of $25^{\circ} \mathrm{C}$ to a minimum of $70^{\circ} \mathrm{C}$ for different applications in the health Center.

[25] Investigated the utilization of solar energy to satisfy hot water demands in Nigeria and makes a model for water heating system. Through modeling, the system efficiency and factors influencing the system performance are estimated. This study looks to model a thermo-siphon system, which relates the impact of efficiency and furthermore a gross area of the collector on the volumetric flow, from experimental results in Akure, Nigeria. Thermosyphon systems, being the most appropriate for the climate condition of Nigeria, were assessed and evaluated. The outcome of the examination indicates that if the efficiency of the system is increased, the area is increased bringing about an increase in the volumetric flow, which can be utilized to assess the quantity of water being heated per time.

In a research carried out by [26], a microcontroller-based active solar water heating system was designed and constructed utilizing local materials for its operation. The system components are: $25 \mathrm{~m}^{2}$ of collectors with $1.5 \mathrm{~m}^{2}$ each, 2500 liters of storage tank, DC pump (12v) and PV module. The performance factors and energy cost investigations have likewise conducted. The active solar water heating system was proposed because of the daily demands of hot water. They recommended that the system can be used on a household scale for hot water production and would be economically viable even with the expected high initial cost and high payback period.

According to a study by [27]., they designed, constructed and simulated active solar water heating system for household hot water application under the climate conditions of Zaria Nigeria with latitude $11.2^{\circ} \mathrm{N}$ and longitude $7.8^{\circ} \mathrm{N}$ utilizing TRNSYS 16 program. The system comprises of a flat plate solar collector, with an area of $2.2 \mathrm{~m}^{2}$ tilted at an angle of $12^{0}$ from horizontal, an insulated vertical storage tank of 100L capacity, interconnecting pipes and a DC pump. The predicted result suggested that the system would be capable of supplying daily household hot water of 100 liters at least temperature of $61^{\circ} \mathrm{C}$ by the day's end (5; $\left.00 \mathrm{pm}\right)$ for the most part of the year aside from the period of July where the tank temperature dropped to temperature under $34^{\circ} \mathrm{C}$ by the day's end.

[28] Designed, constructed and conducted an experimental analysis of flow inside collector of natural circulation solar water heating system. The system was tested at Ado-Ekiti, Nigeria on latitude $7.5^{\circ} \mathrm{N}$. The outcome demonstrates that the system execution depends particularly on both the flow rate through the collector and the solar radiation. Daily investigation of the system demonstrates that collector efficiency is high particularly around late morning when the collector receives the highest solar radiation. During the test, the outcomes indicated that the system displayed the ideal flow rate of $0.1 \mathrm{kgs} / \mathrm{m}^{2}$ at highest efficiency of a collector of $68.5 \%$. Likewise, the average daily efficiency of the system was $57.7 \%$ and the maximum water temperature acquired was $83.5^{\circ} \mathrm{C}$ while the greatest ambient temperature got was $34.5^{\circ} \mathrm{C}$.

\section{DISCUSSION}

Solar water heating potentials in the country are very bright as the nation being well blessed with solar energy resources. Most of the populace and especially the rural inhabitants accordingly resort to fuel-wood for water heating and other energy demands. A review led in 1991 indicates that about half of the energy demands in the nation are gotten from wood-fuels [29]. There are 
environmental concerns emerging from deforestation through the exhaustion of available fuel-wood in the nation. The consumption of hot water in educational sector, hospital, and different segments of the Nigerian economy are very high. Potentials of hot water in different sectors of the economy in the country are provides in the Table 1.

Table 1: Hot Water Potential in various areas of the Nigerian Economy

\begin{tabular}{|l|l|}
\hline Sector & Capacity \\
\hline Household & 20 million households \\
\hline Agriculture [30] & $\begin{array}{l}330,000 \text { square km of cropland (only 0.7\% has } \\
\text { been irrigated) }\end{array}$ \\
\hline Health [31] & $\begin{array}{l}14,000(7,210 \text { are operated by Local Government } \\
\text { Hospitals Councils) }\end{array}$ \\
\hline Education [31] & $\begin{array}{l}40,000 \quad \text { (Primary schools); 6,500 (Secondary } \\
\text { Schools); 40 (Universities) }\end{array}$ \\
\hline Offices & $\begin{array}{l}\text { Federal Ministries/Parastatals; State Ministries; } \\
\text { Local Government Offices; Private Sector } \\
\text { establishments }\end{array}$ \\
\hline
\end{tabular}

Several research works involving design, modeling, simulation, and testing of solar water heaters have been carried out within the country [32]. Many prototypes of these systems have been developed and optimized and are ready to be commercialized. Some systems have been installed in homes and hospital establishments in the country. Generally, solar water heating systems have not been widely adopted in the country, as is the case in some other developed and developing nations. Some reasons for this include: poor awareness, Poor financing for research, improvement and training among others.

Based on the review of the literature on solar water heater, it has been found that solar water heater was widely investigated both analytically and experimentally. A number of studies have been carried out in order to investigate the effect of various parameters on the performance of solar water heater. Solar water heaters works under both natural and forced circulation mode. From the view point of utilization, thermosyphon solar water heater occupies a good position in domestic applications due to its ease of operation without the aid of any external energy. But, as observed from the literature, most of the research works have been conducted in natural circulation mode only. It is also found that most of the researchers from the literature used flat plate collectors as a solar thermal collection system, the choice of flat plate collectors for heating water was simply because the system is cheap, simple to construct and the cost of maintenance is little and also collects both the diffuse and direct components of solar radiation. As shown in the aforementioned literature, there is limited work with respect to long-term thermal and economic analyses of a solar water heating system. Furthermore, no optimal design studies with a relatively detailed model of each component in such system and among the simulation programs TRNSYS has been extensively employed for design and optimization of solar hot water system. On the other hand, around $50^{\circ} \mathrm{C}$ to $80^{\circ} \mathrm{C}$ attained from the literature depending on solar radiation, weather conditions of the research location and solar collector system efficiency.

The amount of cloud cover present can seriously affect the performance of a solar water heating system. The cloud cover which is an ever present in the Nigerian climate has been no studies to show based on the reviewed literature. The selection of an optimum collector area is important to achieve adequate performance [33-34].

\section{CONCLUSION}

After reviewing all the available literature on solar water heating, it was observed that majority of the researchers particularly in Nigeria restricted their study in small scale and within the academic environment. It is on this basis that there is still need for research in this area of solar water heating being a renewable energy. Apart from contribution to the knowledge, it also serves as a public enlightenment to intimate the Nigerian public with idea of integrating the solar water heating system into the building hospital and organizations. Adoption level of solar water heating in the Nigerian economy is exceptionally low right now, in spite of the way that numerous models of the systems have been studied and developed in the nation. Tremendous potentials exist in many sectors in Nigeria such as, health, education, agriculture and industrial.

\section{REFERENCES}

1. Bennet T. (2007): "solar thermal water heating, a simplified modeling approach and potential application for CHBE, thesis. University of British Columbia. Sustainability office.

2. Taylor P.B. (2001): "Energy and thermal performance in the residential sector," unpublished Ph.D. thesis, Potchefstroom University, South Africa. 
3. Agbo, S.N. and O.U. Oparaku. (2006). "Positive and Future Prospects of Solar Water Heating in Nigeria". Pacific Journal of Science and Technology. 7(2):191-198.

4. Akuffo, F.O., and Jackson E.A.(1998) "Simulation studies on a compact solar water heater in the tropics." Solar \& Wind Technology. Vol. 5: pp 229-237.

5. Kalogirou, S. (2008) "Modeling and Design of Solar Energy Systems including solar economics". Cyprus University of Technology, Limassol, Cyprus. [Online] available from http://www.eolss.net/sample-chapters/c08/e6-106-35.pdf (accessed 16- 03- 2017)

6. Patel K, Pragna P. and Jatin P. (2012): Review of solar water heating system. International Journal of Advanced Engineering Technology. Vol. 3(4) pp. 146-149

7. Han Y.M, Wang R.Z and Dai Y.J (2009): Thermal stratification within the water tank. Renewable and sustainable Energy Reviews. Vol. 13 pp. 1014-1026.

8. Parent M.G, Vander Meer T.H and Hollands K.G.T (1990): Natural convection heat exchangers in solar water heating systems. Theory and experiment, solar energy. Vol. 45 pp. 43-52

9. Bello, M.B., Danshehu, B.G., and Sambo, A.S. 1990. "Experimental Studies with a Mains Connected Solar Water Heater". Nigerian Journal. of Solar Energy. 9:68-77.

10. Arinze E.A, Adefila S.S, and Folayan C.O (1988) "Argumentation of energy collector systems in flat plate collectors by sun tracking for various locations in Northern Nigeria”. Nigerian Journal of solar energy. Vol.7, pp. 94.

11. Sambo A.S and Bello M.B (1990) "An experimental Evaluation of collectors for thermosyphon Solar water heater" Nigeria journal of solar energy. Vol. 9 pp. 223-238.

12. Rikoto I.I, (2014): Design, construction and performance analysis of solar water heating system for Bayero University Kano, New Campus clinic. M.Eng. (Energy Engineering) Dissertation, Bayero University, Kano. Nigeria

13. Dashehu B.G and Garba B. (2003)."Effect of absorber orientation on the performance of solar flat plate collector" Nigerian Journal of Renewable Energy. Vol.12, No 1\&2 pp. 38-43

14. Agbo S. N and Okeke CE (2007) "correlation between collector performance and tube spacing for various absorber plate materials in a natural circulation solar water heater". Trends and applied sources research. Vol.2 (3) pp. 251-254.

15. Samson A.A (2013) "Performance of solar water heater in Akure, Nigeria" Journal of energy Technologies and policies. Vol. 3 No 6 ISSN 2225- 0573 www.iiste.org

16. Eze J.I and Ojike O. (2012)."Analysis of thermal efficiency of a passive solar water heater" International journal of Physical sciences. vol. 7 (22), pp. 2891-2896.

17. Basil O. (2013) "Thermo-siphon solar water heater" international journal of Engineering and technology vol.3, No.3 access on 15/09/2013 from www.iet-journals.org

18. Agbo S.N and Unachukwu G.O (2007) "Design features of domestic thermosyphon solar water heater for an averaged sized family in Nsukka Urban "Trends in applied science research vol 2 p $224-270$

19. Ogueke N. V, Anyanwu E. E. and Ekechukwu O. V. (2009), A review of solar water heating systems, Journal of Renewable and Sustainable Energy, Vol. 1043106.

20. Nosa Andrew Ogie, Ikponmwosa Oghogho and Julius Jesumirewhe (2013), Design and construction of a solar water heater based on the thermosyphon principle. Journal of fundamentals of Renewable Energy and applications vol.3 Warri Delta State, Nigeria

21. Zwalnan, J. (2015): design a compact solar water heater for domestic and small scale Industrial application. Published M.Eng Degree Dissertation Report. Department of Mechanical Engineering. Ahmadu Bello University, Zaria. Nigeria

22. Ityona .A (2003): design a compact solar water heater for domestic and small scale industrial application. Unpublished B.Eng. Degree Project Report. Department of Mechanical Engineering. Ahmadu Bello University, Zaria. Nigeria.

23. Sayyadi Sanda (2016), Design, Simulation Construction And Testing Of A Thermosyphon Solar Water Heater For A Block In Postgraduate Hostel In Ahmadu Bello University, Zaria Published M.Eng Degree Dissertation Report. Department of Mechanical Engineering. Ahmadu Bello University, Zaria. Nigeria.

24. Ismail Isa Rikoto, Mohammad Bashir Abdurrahman, Mohammad Hassan Idris, Mahmoud Muhammad Garba and Mohammed Kabiru Halidu (2015), Design, Construction and Installation of 250-Liter Capacity Solar Water Heating System at Danjawa Renewable Energy Model Village. International Journal of Engineering Sciences, Vol (4), No (3), March, 2015. pp. 39-44

25. Ijemaru Gerald Kelechi, Adamu Murtala Zungeru, Obatoke Emmanuel Ayobami, Hussaini Habibu, Ajayi Felix Olugbenga (2014), Design and Modeling of a Solar Water Heating System, Industrial Engineering Letters, Vol.4, No.12, 2014

26. I.A Odigwe, O.O Ologun, O.A Olatokun, A.F Agbetuyi, A.A Awelewa and I.A Samuel (2013), a microcontroller-based active solar water heating system for domestic applications, International Journal of Renewable Energy Research, Vol. 3 No. 4 
27. Z.S Johnson, N.S Yohanna, K.M Peter (2015), Performance Simulation of an Active Solar Water Heating System under the Weather of Zaria Using TRNSYS, International Journal of Scientific \& Engineering Research, Volume 6, Issue 3

28. Bukola Balaji, Flow Design and collector Performance of natural circulation solar water heater,Int.J.Applied Science,713,2006

29. Energy Commission of Nigeria. 1991. “A National Energy Survey Report Presented to the Commission”. ECN: Lagos, Nigeria

30. World Bank. 1999. "World Development Report (1998/99)”. World Bank: Washington, DC.

31. Federal Office of Statistics. 1996. "Annual Abstract of Statistics”. FOS: Lagos, Nigeria

32. Enibe, S.O and Iloeje, C.O. (1994).’Development of Thermosyphon Solar water Heater, International Project Report”. National Centre for Energy Research and Development: Nigeria

33. Agbo, S.N., Unachukwu, G.O., Enibe, S.O., and Okeke, C.E. 2005. "Solar Water Heating for Resident University Students". Nig. J. of Solar Energy. 15:85-92.

34. Samuel A. (2011) "Analysis of the performance profile of the NCERD Thermosyphon solar water heater "Journal of Energy in Southern Africa • Vol. 22, No 2 